\title{
REVITALISASI DAN PELESTARIAN SUMBERDAYA AIR PADA MASYARAKAT DESA
}

\author{
Anies Fuady1, Andy Amirulloh2, Yuspriyono3, Andri Aryanto2, Moh. Basyiruddin3, \\ Zainul Abidin4, Muhamad Yuma Meidiansyah3, Isvaro Amna Maliya4, Iud \\ Maisyaroh4, Nurlaila La Dana4, Nurul Khoirini3 \\ 1Fakultas Keguruan dan Ilmu Pendidikan, Universitas Islam Malang \\ 2Fakultas Teknik, Universitas Islam Malang \\ 3Fakultas Ekonomi dan Bisnis, Universitas Islam Malang \\ 4Fakultas Agama Islam, Universitas Islam Malang \\ Korespondensi email: aniesfuady@unisma.ac.id
}

\begin{abstract}
ABSTRAK
Kearifan lokal sedang menghadapi tantangan yang mengancam eksistensi dikarenakan perkembangan teknologi yang semakin berkembang. Memahami kearifan secara menyeluruh akan menumbuhkan kesadaran bahwa kearifan lokal sangat penting dalam mengelola SDA dan melestarikan lingkungan. Tujuan pengabdian ini adalah untuk merevitalisasi dan melestarikan kearifan lokal masyarakat adat di Desa Tlogosari Kec.Tirtoyudo Jawa Timur. Manfaat pengabdian ini akan digunakan untuk revitalisasi pelestarian kearifan lokal, merevitalisasi nilai-nilai dan norma-norma budaya agar dapat menata kehidupan masyarakat. Model revitalisasi dan pelestarian kearifan lokal dalam mengelola sumberdaya air pada masyarakat yang dilakukan melalui pencarian mata air dan pendukung kearifan local sebagai bagian dari warisan budaya. Revitalisasi dan pelestarian kearifan lokal dalam mengelola sumberdaya air pada masyarakat yang menghasilkan pengelolaan dan pemanfaatan sumberdaya air sebagai urat nadi yang dapat menjamin keberlangsungan kehidupan masyarakatnya.
\end{abstract}

Kata Kunci: revitalisasi; kearifan; sumberdaya air.

\section{PENDAHULUAN}

Indonesia merupakan suatu negara yang memiliki berbagai macam keanekaragaman budaya dari berbagai suku bangsa yang tersebar di berbagai daerah (Hariyanto, 2016). Kebudayaan Indonesia yang beranekaragam ini merupakan sebuah kekayaan intelektual dan kultural. Keberadaanya dapat menjadi potensi sekaligus tantangan untuk dipertahankan sebagai bagian dari warisan budaya yang perlu dilestarikan. Nilai-nilai tradisional budaya pada tempat, waktu, dan masyarakat yang berbeda ini mengandung banyak kearifan local yang masih sangat relevan dengan kondisi saat ini (Asri, 2018).

Kebudayaan bersifat dinamis, terus berkembang, apalagi jika pelaku-pelaku kebudayaan itu dikembangkan potensinya dan digalakkan dinamikanya melalui proses pendidikan (Tilaar, 1999). Setiap daerah di Indonesia memiliki kearifan lokal berbeda-beda yang disebabkan oleh adanya proses interaksi antara manusia dengan lingkungannya dalam rangka memenuhi berbagai kebutuhan hidupnya (Ariyanto et al., 2014; Marfai, 2016). Pengalaman dalam memenuhi kebutuhan hidup tersebut memunculkan berbagai 
sistem pengetahuan baik yang berhubungan dengan lingkungan maupun sosial (Rosala, 2016).

Kearifan lokal merupakan salah satu sumber pengetahuan (kebudayaan) masyarakat dapat ditemukan dalam tradisi dan sejarah, pendidikan formal dan informal, seni, agama serta interpretasi kreatif lainnya (Ulia, Ismiyanti, \& Setiana, 2019). Kearifan lokal merupakan salah satu produk kebudayaan suatu masyarakat yang terlahir karena adanya kebutuhan akan nilai, norma dan aturan untuk menjadi model dalam melakukan suatu tindakan. Sehubungan dengan konsep ini Forde. Hilman \& Hendriawan (2018) mengemukakan bahwa pada hakikatnya hubungan antara kegiatan manusia dengan lingkungan alamnya dijembatani oleh pola-pola kebudayaan yang dimiliki manusia.

Dalam mengelola dan memanfaatkan lingkungan hidup untuk memenuhi kebutuhannya, banyak komunitas lokal di Indonesia yang memiliki pedoman tentang nilainilai budaya yang mereka miliki (Ariyanto et al., 2014). Demikian halnya dengan pengelolaan dan pemanfaatan lingkungan hidup pada masyarakat Desa Tlogosari Kecamatan Tirtoyudo di Provensi Jawa Timur.

Kearifan lokal di Desa Tlogosari masih tetap dijalankan sampai saat ini karena merupakan amanah leluhur yang harus dilaksanakan sesuai dengan aturan yang ada. Bentuk kearifan lokal yang berhubungan dengan pengelolaan sumberdaya alam (khususnya sumberdaya air), serta yang berhubungan dengan kehidupan sehari-hari ini merupakan suatu aturan atau norma yang mengikat dan mengatur kehidupan masyarakat (Hilman \& Hendriawan, 2018).

Wilayah Desa Tlogosari mempnyai mempunyai ciri geologis berupa tanah yang subur untuk lahan perkebunan. Contohya, kopi, singkong, buah-buahan dan lain sebagainya. Disamping lahannya yang subur, tlogosari juga mempunyai sumber mata air yang cukup melimpah. Tapi sayangnya terkadang juga banyak kendala pada sumber mata air yang sering dugunakan oleh masyarakat tlogosari.

Sumber daya air adalah sumber daya berupa air yang berpotensi dan berguna bagi makhluk hidup. Contoh dari penggunaan air adalah dalam bidang pertania, industry, rumah tangga, rekreasi dan aktivitas lingkupan. Disini dapat terbukti bahwa air sangatlah penting bagi kelangsungan hidup manusia (Manik, 2016). Visi dan misi pengelolaan sumber daya air antara lain harus mewujudkan kemanfaatan sumber daya air bagi kesejahteraan masyarakat Tlogosari (Sudarwanto, 2015). Dengan visi ini, maka misi pengelolaan sumber daya air adalah pendayagunaan sumber daya air, pengendalian dan penanggulangan daya rusak air, peningkatan ketersediaan dan sisten prasarana dan sarananya.

Kearifan lokal yang sudah berlaku di suatu masyarakat yang sifatnya turun menurun dan berhubungan erat dengan kelestarian lingkungannya perlu dilestarikan. Dengan memahami kearifan lokal akan semakin nyata bahwa kearifan lokal menjadi modal penting dalam pengelolaan sumber daya alam dan pelestarian lingkungan. Dengan upaya pengabdian ini akan diperoleh pemahaman yang holistik tentang model revitalisasi dan pelestarian kearifan lokal masyarakat (Marfai, 2016).

Dengan memperhatikan perubahan-perubahan iklim antara musim hujan dan musim kemarau yang tidak menentu dan keterbatasan penyebaran sumberdaya air, maka dalam artikel ini akan dijelaskan dalam memeperbaiki sumberdaya air dengan mengelola sumber daya air Desa Tlogosari demi kemudahan masyarakat dalam memanfaatkan sumberdaya air (Renjaan \& Erare, 2013).

\section{METODE}

Objek pengabdian ini adalah realitas sosial yang mencakup gerak individu dan lembaga di dalamnya, dengan identitas, nilai, budaya, tradisi, masyarakat lokal kampung 
adat. Data deskriptif yang dihasilkan dalam survey dalam pengabdian, baik dalam bentuk data lisan, tertulis, atau dokumen-dokumen dari sumber berkompeten dan para informan (kunci dan ahli) dikumpulkan dengan menggunakan teknik dan metode pengabdian eksploratif kualitatif. Peneliti sebagai instrument turun langsung ke lapangan dengan pengamatan terlibat atau partisipatoris untuk mengadakan pengamatan, pencatatan, dan pengambilan dokumentasi foto, rekaman suara dan lain sebagainya selama proses-proses pengabdian berlangsung.

Teknik pengabdian eksploratif ini dilakukan untuk mendapatkan data berupa keterangan deskriptif yang rinci mengenai makna suatu benda, tindakan, interaksi dan peristiwaperistiwa yang terkait dalam kehidupan masyarakat. Dalam hal ini, peneliti mengeksplorasi nilai-nilai kearifan dalam tindakan budaya masyarakat lokal untuk menghasilkan model revitalisasi dan pelestarian kearifan lokal dalam mengelola sumberdaya air pada Masyarakat di Desa Tlogosari Kec. Tirtoyudo Jawa Timur.

\section{HASIL DAN PEMBAHASAN}

Desa Tlogosari terletak di Kecamatan Tirtoyudo Kabupaten Malang, sekitar 50 km dari Kota Malang merupakan desa yang terdiri dari, 43 dusun, 62 RW dan 299 RT. Secara administratif, Desa Tlogosari dikelilingi oleh desa lainnya yang ada di Kecamatan Tirtoyudo Kabupaten Malang. Di sebelah utara berbatasan langsung dengan Desa Sukorejo. Sedangkan di sebelah timur langsung dengan desa tamansari. Di sebelah selatan berbatasan dengan sukodono. Lalu, di sebelah barat berbatasan dengan desa tirtoyudo.

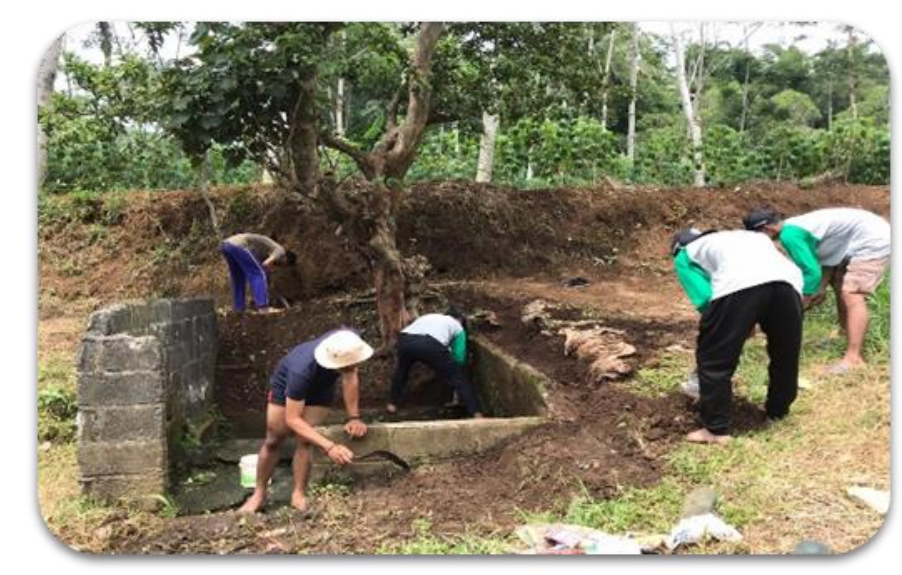

Gambar 1. Pembersihan lingkungan sumur

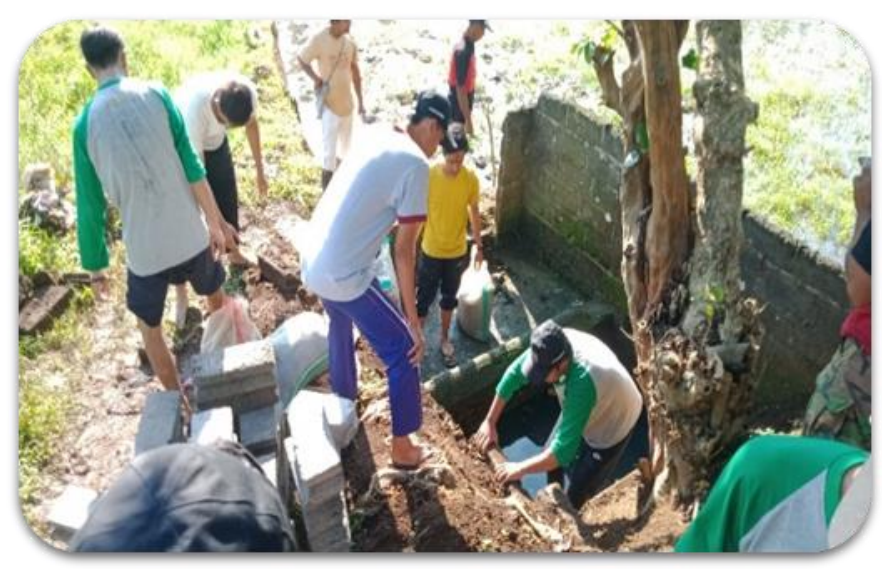

Gambar 2. Pemasangan tembok sumur 
Model Revitalisasi dan Pelestarian Kearifan lokal dalam mengelola sumberdaya air pada masyarakat adat Desa Tlogosari Kec.Tirtoyudo Jawa Timur:

1. Melakukan pembersihan semak belukar; Pembersihan dilakukan untuk mempermudah ketika melakukan Revitalisasi Bersama masyarakat dan juga memperindah lingkungan di sekitar sumber, alat yang digunakan untuk pembersihan adalah Arit, Parang dan Cangkul.

2. Proses pembangunan Bersama warga; Masyrakat dan Mahasiswa melakukan gotong royong dalam membangun sumber air.

3. Pengelolaan dan pemanfaatan sumberdaya air; Sumberdaya air yang terdapat di Desa Tlogosari digunakan untuk memenuhi kebutuhan sehari-hari dan Masyarakat hanya memanfaatkan sumber mata air ini untuk semua kebutuhan hidup sehari-hari seperti mandi, cuci baju dan cuci motor

Prinsip ini memiliki makna yang sangat dalam tentang arti penting hutan bagi kehidupan masyarakat Desa Tlogosari. Ketersediaan air tanah salah saunya sangat tergantung dari lestarinya hutan-hutan tersebut. Slogan tersebut disosialisasikan dengan cara dipampang di tengah perkampungan serta senantiasa disosialisasikan oleh keluarga dan lembaga adat melalui aturan adat yang berupa tabu kepada setiap individu warga masyarakat Desa Tlogosari.

\section{KESIMPULAN}

Model Revitalisasi dan pelestarian kearifan lokal dalam mengelolah sumberdaya air pada masyarakat Desa Tlogosari Kecamatan Tirtoyudo Kabupaten Malang Jawa Timur dilakukan melalui pencarian sumber mata air dengan menyusuri perkebunan-perkebunan warga sekitar sehingga ditemukanlah sumber itu dalam keadaan tidak layak karna ditutupi oleh semak-semak belukar. Revitalisasi dan pelestarian kearifan lokal dalam mengelolah sumberdaya air pada masyarakat Desa Tlogosari Kecamatan Tirtoyudo Kabupaten Malang Jawa Timur menghasilkan manfaat bagi masyarakat sekitar dan juga sumber tersebut sebagai alternatif bagi masyarakat ketika masa kemarau.

\section{DAFTAR RUJUKAN}

Ariyanto, Rachman, I., \& Toknok, B. (2014). Kearifan Masyarakat Lokal dalam Pengelolaan Hutan di Desa Rano Kecamatan Balaesang Tanjung Kabupaten Donggala. Warta Rimba, 2(2), 84-91.

Asri, D. P. B. (2018). Perlindungan Hukum Preventif Terhadap Ekspresi Budaya Tradisional Di Daerah Istimewa Yogyakarta Berdasarkan Undang-Undang Nomor 28 Tahun 2014 Tentang Hak Cipta. Journal of Intellectual Property, 1(1), 13-23.

Hariyanto, O. I. B. (2016). Destinasi Wisata Budaya dan Religi di Cirebon. Jurnal Ecodemica: Jurnal Ekonomi, Manajemen, Dan Bisnis, 4(2), 214-222. https://doi.org/10.31311/jeco.v4i2.830

Hilman, I., \& Hendriawan, N. (2018). Model Revitalisasi dan Pelestarian Kearifan Lokal Dalam Mengelola Sumberdaya Air Pada Masyarakat Adat Kampung Kuta Kabupaten Ciamis Jawa Barat. In Prosiding Seminar Nasional Geografi UMS IX 2018 RESTORASI SUNGAI: TANTANGAN DAN SOLUSI PEMBANGUNAN BERKELANJUTAN (pp. 308315).

Manik, K. E. S. (2016). Pengolahan Lingkungan Hidup (2nd ed.). Jakarta: Kencana.

Marfai, M. A. (2016). Pengantar Etika Lingkungan dan Kearifan Lokal (Ruslan). Yogyakarta: Gadjah Mada University Press.

Renjaan, H., \& Erare, S. R. (2013). Pengelolaan Hutan di Era Otonomi Daerah. Patriot, 6(1), 54-101. 
http://repository.ipb.ac.id/jspui/bitstream/123456789/24680/3/prosiding_pekan _ilmiah_kehutanan_nasional_III-6.pdf

Rosala, D. (2016). Pembelajaran Seni Budaya Berbasis Kearifan Lokal Dalam Upaya Membangun Pendidikan Karakter Siswa Di Sekolah Dasar. Ritme Jurnal Seni Dan Desain Serta Pembelajarannya, 2(1), 16-25.

Sudarwanto, A. S. (2015). Dampak Dibatalkannya Undang-Undang Nomor 7 Tahun 2004 Tentang Sumber Daya Air Terhadap Manajemen Air Untuk Kesejahteraan Masyarakat. Yustisia Jurnal Hukum, 92(2), 456-474. https://doi.org/10.20961/yustisia.v92i0.3828

Tilaar, H. A. R. (1999). Pendidikan, kebudayaan dan masyarakat madani Indonesia : strategi reformasi pendidikan nasional (1st ed.). Bandung: Remaja Rosdakarya.

Ulia, N., Ismiyanti, Y., \& Setiana, L. N. (2019). Meningkatkan Literasi Melalui Bahan Ajar Tematik Saintifik Berbasis Kearifan Lokal. Jurnal Inovasi Hasil Pengabdian Masyarakat (JIPEMAS), 2(2), 150-160. https://doi.org/10.33474/jipemas.v2i2.3402 